\title{
PENDIDIKAN (AGAMA) PLURALIS: UPAYA MENCIPTAKAN KERUKUNAN BANGSA
}

\author{
Muhammad Walid \\ Fakultas Tarbiyah Universitas Islam Negeri (UIN) Malang \\ Jl. Gajayana 50 Malang 65144 Telp. 0341-55135
}

\begin{abstract}
Religious education has to give contribution to form pluralistic attitude that appreciates the truth of other religions. The claim of being the only true religion by various religious followers may result in horrific conflicts. It is dangerous when religion is used to justify sadistic act in many conflicts. Therefore, religious education is very important to develop religiosity and to improve religious tolerance. As a social process, education is a means of transferring religious values and knowledge to the religious followers that, in turn, form their religious attitudes. Consequently, if religion is learned exclusively, the output will be exclusive. Conversely, if religion is learned openly or inclusively, the output will be openminded, it means they can understand the others.
\end{abstract}

Key words: education, religion, pluralism

\section{Pendahuluan}

Albert Schweitzer (1875-1965), dalam Reverence for Life: An Anthology of Selected Writing, pernah mengajukan pertanyaan retoris, is religion a force in the spritual life of our age? Di satu sisi, masih berduyun-duyun orang memeluk agama, rumah ibadah terus bertambah, dan banyak orang sholeh yang rindu beragama. Namun, di sisi lain, agama makin kehilangan perannya, bahkan agama dalam sejarahnya selalu memiliki "wajah kekerasan". Mari kita perhatikan, perang Katolik dan Protestan yang menggemparkan di abad 16, pembantaian orang-orang Yahudi oleh orangorang Jerman yang Kristen, perang Salib antara Islam-Kristen yang berlangsung selama lebih dari 500 tahun, ataupun beberapa kekerasan bernuansakan agama yang terjadi dalam beberapa tahun terakhir. 
Perjalanan sejarah bangsa Indonesia sendiri dalam satu dekade ini juga banyak diwarnai dengan kekerasan-kekerasan, dan itupun juga kekerasan atas nama agama. Fenomena tersebut bisa dilihat mulai dari kekerasan yang terjadi di Ambon (1995), Poso (1991), peristiwa peledakan bom di malam Natal (2000) di Atrium Senin Jakarta, Bom Bali (2002) yang menewaskan hampir 200 nyawa, peledakan bom di hotel JW Marriot (2003), Bom di Tentena dan terakhir yang masih terngiang di telinga kita, yaitu Bom Bali II, belum lagi peristiwa-peristiwa kecil yang terjadi di berbagai penjuru Indonesia yang bisa dikategorikan berbau agama. Hal ini seakan mempertegas bahwa pemahaman masyarakat terhadapagama masih bersifat eksklusif dan intoleran.

Pemahaman agama yang demikian tentu sangat tidak menguntungkan bagi bangsa Indonesia yang secara realitas sangat beragam dan plural, baik dari segi ras, kepercayaan dan agama. Keberagaman masyarakat Indonesia yang tidak diikuti dengan pemahaman yang inklusif dan toleran inilah yang sering menimbulkan kekerasan demi kekerasan tersebut.

Sebagai negara yang menempatkan agama sebagai falsafah dalam kehidupan berbangsa adalah penting untuk melihat kembali peran pendidikan agama di lingkungan sekolah untuk mereduksi konflik yang sering muncul di tanah air. Apa yang salah dengan pendidikan agama, sehingga agama yang seharusnya tampil sebagai pengayom dan terompet moral yang keras dalam berbagai dimensi kehidupan, ternyata justru sering dituduh sebagai biang munculnya kekerasan. Agama yang semestinya hadir sebagai energi sosial untuk melawan ketidakadilan, mencegah konflik ternyata menjadi faktor dominan meletusnya konflik. Oleh karena itulah, memberikan pemahaman agama yang inklusif dan toleran yang mampu melahirkan kerja sama di bidang kemanusiaan melalui pendidikan agama sangat mutlak diperlukan di Indonesia dalam rangka untuk meredam konflik, dan mencegah timbulnya kekerasan atas nama agama, serta menciptakan kerukunan bangsa.

\section{Masalah-Masalah Pendidikan Agama}

Gambaran diatas menunjukkan betapa pemahaman agama masyarakat Indonesia masih diwamai oleh watak eksklusif dan intoleran, yang bisa 
saja disampaikan dalam ruang-ruang publik, sepertisekolah, madrasah, atau bahkan pesantren. Dalam konteks demikian, maka ada persoalan serius yang terjadi dalam pendidikan agama di Indonesia. Hal ini bisa dilihat dari visi, tujuan, kurikulum, pilihan buku wajib, literatur, dan yang tidak kalah pentingnya adalah guru yang menyampaikan dan penyikapannya terhadap kemajemukan yang masih menyisakan banyak problematika. Ada dugaan bahwa pengajaran agama yang dilakukan oleh guru-guru agama lebih condong menekankan pada sisi formalisme, ritualisme dan eksklusivisme (Jawa Pos, 11 Mei 2003).

Hal ini terjadi karena Guru-guru Pendidikan Agama di sekolahsekolah tidak pluralis, sehingga pengajaran agama hanya berhenti pada persoalan-persoalan ibadah semata dan bersifat kognitif dan belum sampai kepada bagaimana merangsang dan mendorong siswa terlibat dalam pemahaman agama yang lebih inklusif serta secara afektif membuahkan transformasi diri dalam tataran nilai. Tidak berlebihan jika siswa sering mendapatkan pengetahuan agama yang berbasis eksklusivisme, di antaranya siswa saling mengkafirkan, menyalahkan agama lain, kurang menghormati orang yang berbeda agama, menganggap agamanya yang benar dan yang lain salah, karena itu kehadiran agama lain dianggap sebagai ancaman, akibatnya benih-benih konflik terus bermunculan, sehingga agama yang dipahami siswa adalah saling memusuhi antara satu dengan yang lain (eksklusive). Hal inilah yang pada gilirannya sering menjadi pemicu kekerasan atas nama agama ketika kesadaran agama yang eksklusif muncul di tengah-tengah masyarakat.

Di samping itu, selama ini ada persepsi yang keliru tentang fungsi dan peran pendidikan. Pendidikan terutama pendidikan agama yang semestinya bertujuan utama untuk membentuk peradaban dan pendewasaan sikap, ternyata telah menjadi pendidikan yang nomor dua setelah pemenuhan kebutuhan ekonomi. Hal ini juga pernah disinggung oleh mantan menteri Pendidikan Nasional, Prof. Dr. Abdul Malik Fadjar pada "Simposium Kebangkitan Jiwa" yang diselenggarakan oleh Forum Kebangkitan Jiwa, pada Rabu, 6 Maret 2002, bahwa pendidikan telah lama menjadi alat untuk mengejar pertumbuhan ekonomi belaka, dan bukan diorientasikan pada 
pembentukan peradaban, sehingga telah terjadi proses dehumanisasi dalam pendidikan ( Pikiran Rakyat, 7 Maret 2002 ).

Pernyataan mantan Mendiknas tersebut jelas menggambarkan bahwa umumnya masyarakat Indonesia menjadikan pendidikan sebagai sarana untuk mengejar ekonomi. Orientasi ini menyebabkan pendidikan yang berorientasi pada peningkatan moral dan mental spritual, seperti pendidikan agama menjadi dinomorduakan. Tidak heran kalau ada asumsi bahwa salah satu penyebab lunturnya nilai-nilai toleransi dan pluralisme agama pada masyarakat Indonesia terjadi karena nilai-nilai pendidikan agama yang diajarkan di sekolah-sekolah kurang diminati dan dihayati. Dari sini timbul pertanyaan, apa yang salah dengan metode pengajaran agama-agama di dunia pendidikan kita? Apakah tidak diminatinya pendidikan agama disebabkan oleh pergeseran orientasi belaka ataukah pendekatan pengajaran agama yang tidak lagi menarik dan membosankan?

Peringatan Bertrand Russel dalam Education and Social Order (1993) juga patut kita renungkan. "Sejauh pendidikan dipengaruhi oleh agama, maka pendidikan dipengaruhi agama institusional yang memiliki arti politik yang besar. Karena arti politik yang begitu besar, tidak heran jika doktrin yang berkembang adalah doktrin yang eksklusif, superior, dan mengklaim sebagai yang paling benar", kata Russel. Pada gilirannya, tidak terjadi hubungan yang harmonis dan terbuka dalam mensikapi agama-agama lain. Agama hanya dijadikan sebagai ideologi politik yang kental aroma konflik dan pertikaian antar sesama umat beragama.

Di pihak lain, rezim orde baru selalu mencurigai kelompok-kelompok Islam lewat khutbah, dakwah dan pendidikan. Kecurigaan dan sikap permusuhan yang dilakukan rezim orde baru telah menciptakan kesadaran permusuhan dan pertentangan dari kelompok-kelompok Islam. Akibatnya muncul radikalisasi umat, yang terus-menerus didakwahkan di lembagalembaga pendidikan, seperti sekolah, madrasah, dan pesantren. Politik antiIslam rezim orde baru telah membawa malapetaka yang luar biasa bagi proses pembentukan kesadaran beragama masyarakat secara luas.

Itu sebabnya, politik pendidikan agama yang dimainkan rezim orde baru melalui lembaga pendidikan telah menghancurkan kehidupan masyarakat yang toleran. Bahkan, pendidikan agama didesain dalam ritme 
rezim yang sangat intoleran dan sektarian. Akibatnya, pada dekade-dekade berikutnya, 1990-an hingga sekarang terjadi ledakan kekerasan atas nama agama di Indonesia.

Lain dari itu semua, dalam pelaksanaan pendidikan agama yang sedang berlangsung di sekolah terdapat berbagai kritik. Misalnya, Moch tar Buchori menilai kegagalan pendidikan agama disebabkan karena praktek pendidikannya hanya memperhatikan aspek kognitif semata dari pertumbuhan kesadaran nilai-nilai (agama), dan mengabaikan pembinaan aspek afektif dan kognitif-volitif, yakni kemauan dan tekad untuk mengamalkan nilai-nilai ajaran agama. Akibatnya terjadi kesenjangan antara pengetahuan dan pengamalan, antara gnosis dan praxis dalam kehidupan nilai agama. Dalam praktek pendidikan agama berubah menjadi pengajaran agama, sehingga tidak mampu membentuk pribadi-pribadi Islami (Buchori, 1992).

Di samping itu, Andi Rasdianah mengemukakan beberapa kelemahan lainnya dari pendidikan agama Islam di sekolah, baik dalam pemahaman materi pendidikan agama Islam maupun dalam pelaksanaanya, yaitu: (1) Dalam bidang teologi, ada kecenderungan mengarah pada faham fatalistik, (2) Bidang akhlak berorientasi pada urusan sopan santun dan belırm dipahami sebagai keseluruhan pribadi manusia beragama, (3) Bidang ibadah diajarkan sebagai kegiatan rutin agama dan kurang ditekankan sebagai proses pembentukan kepribadian, (4) Dalam bidang hukum (fiqh) cenderung dipelajari sebagai tata aturan yang tidak akan berubah sepanjang masa, dan kurang memahami dinamika dan jiwa hukum Islam, (5) Agama Islam cenderung diajarkan sebagai dogma dan kurang mengembangkan rasionalitas serta kecintaan pada kemajuan ilmu pengetahuan, (6) Orientasi mempelajari Al-Qur'an masih cenderung pada kemampuan membaca teks, belum mengarah pada pemahaman arti dan penggalian makna (Maimun dkk, (ed), 2003).

Siti Malikhah Towaf juga telah mengamati beberapa kelemahankelemahan pendidikan agama Islam di sekolah, antara lain:

a. Pendekatan masih cenderung normatif, dalam arti pendidikan agama menyajikan norma-norma yang seringkali tanpa illustrasi 
konteks sosial budaya, sehingga peserta didik kurang menghayati nilai-nilai agama sebagai nilai yang hidup dalam keseharian.

b. Kurikulum pendidikan agama Islam yang dirancang di sekolah, sebenarnya lebih menawarkan minimum kompetensi atau informasi, tetapi pihak Guru Pendidikan Agama Islam (GPAI) sering terpaku padanya, sehingga semangat untuk memperkaya kurikulum dengan pengalaman belajar yang bervariasi menjadi kurang tumbuh.

c. Sebagai dampak yang menyertai situasi tersebut di atas, maka GPAI kurang berupaya menggali berbagai metode yang mungkin bisa dipakai untuk pendidikan agama, sehingga pelaksanaan pembelajaran cenderung monoton.

d. Keterbatasan sarana dan prasarana, sehingga pengelolaan cenderung apa adanya. Pendidikan agama yang di klaim sebagai aspek yang paling penting, sering kali kurang diperhatikan sarana prasarana (Towaf, 1996).

\section{Memahami Konsep Pendidikan Pluralis dan Kerukunan Bangsa}

Pendidikan Pluralis bukan pendidikan inklusif, dan bukan pula pendidikan multikultural diambil sebagai salah satu tema pokok (variabel) dengan maksud: pluralis memiliki maknabbahwa seseorang mengakui agama yang dianutnya adalah benar dan tidak menyalahkan agama lain. Sikap yang dikembangkan adalah menghargai, toleran dan bersikap aktif bersamasama agama lain mewujudkan kebersamaan hidup. Dengan demikian, pendidikan pluralis lebih cenderung diartikan proses penyadaran di tengahtengah keaneragaman agama dari pada keanegaraman budaya, suku, etnis, bahasa dan sebagainya.

Pluralisme bukan berarti paham yang hendak menyeragamkan keanekaan, paham ini justru menjunjung tinggi keragaman dan menghargai perbedaan. Titik temu pluralisme bukan pada bentuk peleburan untuk menunggal, akan tetapi pada sikap toleransi terhadap keragaman itu sendiri. Inilah peranan pendidikan agama yang perlu dikedepankan, kini dan di masa depan, di samping peran-peran lain dalam meningkatkan kualitas keberagamaan para pemelukagama. Dengan kata lain, pendidikan pluralis 
menuntun pada kehidupan yang saling menghargai di tengah-tengah keragaman agama dan mengembangkan sikap hidup toleran untuk mewujudkan kehidupan bersama. Jadi, terdapat pesan aktif dan bukan pasif dalam mewujudkan tujuannya.

Sedang pendidikan inklusif memang mengakui adanya keyakinan lain di luar agamanya, tetapi lebih bersifat pasif dalam mewujudkan ide-ide toleransi, keadilan, kebersamaan dengan agama lain. Sementara itu, pendidikan Multikultural lebih cenderung bermakna kepada bermacammacam suku, bahasa, etnis dan sebagainya, dan "bukan" bermacam-macam agama seperti di Indonesia. Sedangkan pembahasan yang dimaksud adalah "kegagalan" Indonesia dalam mengelola pendidikan agama yang disebabkan oleh heteroginitas agama.

Pendidikan pluralis adalah proses penyadaran yang bersendikan toleransi. Pendidikan pluralis ditujukan sebagai usaha komprehensif yang mencegah konflik agama, radikalisme agama, separatisme dan disintegrasi bangsa untuk mewujudkan kerukunan bangsa (Hanif, 2003). Oleh karena itu, toleransi merupakan sikap kewargaan yang tidak spontan, tetapi aktif dan bukan pasif. Sikap toleran harus diinternalisasikan secara terus menerus dan secara aktif, bukan dengan sendirinya. Toleransi harus diajarkan, tidak selesai hanya sebatas wacana. Keputusan Majelis Ulama, keputusan konsili, kesepakatan dewan Gereja, atau kesepakatan tokoh agama tentang toleransi tidak dapat berarti apa-apa tanpa dukungan pendidikan dalam arti luas.

Akan tetapi, urgensi pendidikan pluralis belum dapat dirasakan dunia pendidikan Indonesia. Dalam dunia pendidikan, pluralisme belum begitu dipahami dan dihayati, baik sebagai gagasan maupun praktik sosial-budaya. Pluralisme hanya sering disinggung dalam antropologi, politik dan sosiologi. Padahal, pangkal mengentalnya konflik dan disintegrasi adalah pendidikan agama yang selama ini bersifat eksklusif dan indoktrinasi. Para siswa dijejali pengetahuan tanpa memahami, apalagi menghayati. Posisi guru selalu dianggap sebagai sumber belajar. Parahnya lagi, jika guru memberikan muatan kurikulum yang tidak relevan.

Sebagai contoh, untuk mengukur keberhasilan pendidikan agama lebih didasarkan pada seberapa banyak hafalan kitab suci dan pengetahuan tata cara ritual. Pesan-pesan agama yang diajarkan untuk memperkuat 
keimanan dan solidaritas sesama umat seiman, jarang sekali mendapatkan sentuhan. Cara seperti ini hanya mendorong tumbuhnya keagamaan baru yang berporos pada kulit, belum sampai pada esensi yang sebenarnya.

Ajaran kebenaran mutlak agama seringlebih ditekankan (truth claim). Padahal, pesan-pesan agama penuh dengan toleransi dan pluralisme yang harus dididikkan. Misalnya, sebagaimana yang terdapat dalam disebutkan bahwa sebagai tanda kebesaran Tuhan, Dia menciptakan langit dan bumi dan juga pluralitas bahasa, warna kulit manusia. (Q.S. 20: 22). Wawasan pluralis dalam dunia pendidikan agama merupakan bekal terpenting agar siswa menghargai perbedaan secara tulus, terbuka, dan tidak saling curiga, di samping tetap meningkatkan keimanan dan ketakwaan. Jika tidak ada keterbukaan, maka apapun yang berbeda akan selalu dicurigai dan dianggap musuh serta harus disingkirkan. Siswa yang mempelajari beragam agama dan budaya akan lebih mudah bersikap toleran dari pada mereka yang hanya belajar satu agama.

Pendidikan pluralis bukan mendorong siswa untuk menjalankan ajaran agamanya dengan "seenaknya", tetapi justru mengajarkan untuk taat agama, tanpa menghilangkan identitas keagamaan masing-masing. Wajah agama yang ditampilkan pendidikan pluralis adalah identitas agama yang moderat dan toleran. Salah satu sumbangan terpenting pendidikan pluralis adalah asumsi bahwa semua agama dapat menyumbangkan sesuatu dan dapat berbuat sesuatu secara baik terhadap persoalan-persoalan kehidupan, bukannya satu dapat menyelesaikan semua, apalagi di negara multi-agama seperti Indonesia. Melalui pendidikan pluralis, agama-agama memberikan kontribusi bagi pembangunan bangsa menuju masyarakat yang toleran, berkeadilan, saling menghargai, saling menghormati. Pasalnya, pendidikan agama merupakan pilar penyangga kerukunan umat beragama dan kerukunan umat beragama merupakan pilar kerukunan bangsa (Hanif, 2003).

Oleh karena itu, titik tekan utama pendidikan pluralis terletak pada pemahaman dan upaya untuk hidup bersama dalam konteks berbeda agama dan budaya, baiksecara individual maupun kolektif. Titik tumpu selanjutnya terletak pada pemahaman nilai-nilai bersama (common value) dan upaya kolaboratif mengatasi masalah-masalah bersama, seperti keterbelakangan, 
kemiskinan, kebodohan, ketidakadilan dan sebagainya. Dengan demikian, pendidikan pluralis tidak sekedar untuk memahami keragaman agamapandangan pendidikan inklusif-, tetapi juga memahami nilai-nilai bersama yang dapat di-sharing sebagai dasar hidup bersama. Jika semua dapat dilaksanakan secara normal, maka tujuan pendidikan pluralis yang menanamkan rasa simpati, empati, apresiasi terhadap penganut agama lain akan mudah tercipta, yang pada gilirannya akan terwujud kerukunan bangsa

Kerukunan antar umat beragama. Jika komitmen internal agama dikembangkan dalam kerangka wawasan yang sempit, tentu saja akan melahirkan dinamika hubungan antar pemeluk agama selalu dalam suasana saling curiga dan saling memperkuat diri. Dalam konteks pluralisme tentu saja hal tersebut tidak kondusif bagi kerukunan. Oleh karena itu, wawasan kerukunan perlu dikembangkan kepada kerangka hubungan antaragama secara luas, di mulai dari menyadari bahwa dalam kondisi riil bangsa Indonesia yang hidup dalam keragaman agama diperlukan proyek kerukunan, sehingga keragaman dan harmoni bisa tetap terjamin. Kenyataan sosiologis ini juga didukung oleh ajaran-ajaran normatif yang bersumber dari al-Qur'an dan sunnah Rasul.

Di dalam Islam tidak ada konsep permusuhan atau kebencian terhadap orang yang bukan beragama Islam. Islam justru berusaha untuk menegakkan kehidupan beragama dalam suasana perdamaian, kerukunan dan saling kerjasama dengan orang-orang yang bukan beragama Islam. (Baca...Sururin (ed.), 2005). Hal ini telah dibuktikan oleh Rasulullah ketika beliau membentuk pemerintahan di Kota Madinah. Pada saat itu penduduk Kota Madinah terdiri atas tiga golongan, yaitu golongan Islam, Yahudi dan Nasrani. Beliau membentuk komitmen persamaan hak dan kemerdekaan beragama. Karena penganut agama Nasrani di Madinah pada waktu itu sedikit, maka perhatian Rasulullah banyak tercurah kepada golongan Yahudi. Beliau mengadakan perjanjian dengan golongan Yahudi yang dimaksudkan untuk kepentingan duniawi semata dan tidak sama sekali menyangkut aspek substansi agama seperti masalah akidah dan ibadah. Isi perjanjian yang dikenal dengan Piagam Madinah, itu antara lain: (1) Seluruh penduduk Madinah merupakan satu kesatuan warga yang bebas berfikir dan melakukan agamanya masing-masing serta tidak boleh saling 
mengganggu; (2) Apabila kota Madinah diserang musuh mereka harus mempertahankannya bersama-sama; (3) Apabila salah satu golongan diserang musuh, golongan yang lain harus membantunya; (4) Jika timbul perselisihan, penyelesaiannya di bawah keadilan yang dipimpin oleh Rasulullah.

Konsep hidup berdampingan dan tidak saling bermusuhan antara umat Islam dan golongan agama lain itu juga termuat dalam al-Qur'an yang menyatakan bahwa masing-masing pemeluk agama menyembah Tuhannya sendiri-sendiri, tanpa harus saling dipertukarkan satu sama lain (QS. AlKafirun [109]: 1-6).

Gambaran toleransi Islam seperti itu juga tercermin dalam cara-cara melakukan penyiaran agama Islam. Dakwah Islam tidak boleh dilaksanakan dengan kekerasan atau paksaan, tetapi harus dilakukan dengan cara yang halus, bijaksana, dan menarik. Dakwah kepada orang yang bukan Islam dilakukan dengan jalan memberikan penerangan mengenai keuntungan beragama Islam, mengenai keimanan dalam Islam yang mudah dipahami, mengenai kesederhanaan kewajiban dalam mengamalkan ibadah dan muamalah keagamaan, dasar-dasar kesusilaan yang berprinsip saling menghargai dan sebagainya. Sikap dakwah seperti itulah yang diajarkan pleh al-Qur'an "Tidak ada paksaan dalam (memasuki) agama (Islam) (QS. Al-Baqarah [2]: 256)

Dengan gambaran seperti itu, jelas Islam memiliki semangat toleransi yang tinggi. Namun demikian, toleransi ini hanya terbatas pada masalahmasalah keduniaan, seperti kerjasama dalam bidang sosial budaya, ekonomi, politik, dan masalah lain yang berkaitan dengan keduniaan. Adapun yang berkaitan dengan masalah ibadah dan akidah harus sesuai dengan ajaran agama masing-masing.

\section{Pendidikan (Agama) Pluralis: Upaya Menciptakan Kerukunan Bangsa}

Pengembangan wawasan pluralisme agama sebenarnya sudah beranjak dari tahap sosialisasi dan pemahaman kepada pencarian paradigma teologi dan formalisasi dialog dan kerjasama antarumat beragama. Sosialisasi itu 
antara lain harus dilakukan melalui jalur pendidikan, termasuk pendidikan agama yang berperan besar dalam pembentukan sikap keagamaan. Faktor pendidikan dan pengajaran dalam pembentukan sikap keagamaan dan respon terhadap realitas keagamaan, jelas sangat penting. Karena, sebagai proses sosial, pendidikan dan pengajaran merupakan wahana bagi suatu agama untuk mentransmisikan ajaran-ajarannya. Dengan konsep dasar sebagai proses alih nilai (transfer of value) dan alih pengetahuan (transfer of knowledge), pendidikan berperan menanamkan nilai-nilai dan pengetahuan agama kepada pemeluknya. Nilai-nilai dan pengetahuan kegamaan ini kemudian berpadu membentuk sikap dan prilaku keagamaan. Dengan demikian, kalau dalam proses pendidikan, agama diajarkan sebagai sesuatu yang eksklusif, maka outputnya adalah manusia yang bersifat eksklusif. Sebaliknya, kalau agama diajarkan sebagai sesuatu yang terbuka dan dengan cara yang demokratis, maka hasilnya adalah manusia-manusia yang terbuka dan bisa memahami keadaan orang lain dengan keunikan-keunikan pribadi dan latar belakangnya.

Dengan pendidikan yang demikian, wajar kalau terjadi kekacuan dalam masyarakat, karena pendidikan agama berubah fungsi hanya sekedar pengajaran dan bukan upaya internalisasi nilai-nilai untuk siswa didik. Kekeliruan pelaksanaan pendidikan sehingga menjadi sekedar pengajaran, merupakan hal yang dianggap sebagai penyebabnya sehingga digugat. Dalam konteks kemusykilan hubungan sesama pemeluk agama, tentulah pendidikan agama yang menjadi sorotan. Dalam keadaan seperti ini, pendidikan agama menghadapi problem sekaligus tantangan yang besar, meskipun hal ini sebenarnya merupakan problem dan tantangan pendidikan nasional. Ketika masyarakat Indonesia dewasa ini mengalami berbagai macam krisis, seperti krisis politik, ekonomi, hukum, dan kebudayaan, orang melihatnya sebagai refleksi krisis pendidikan nasional, karena pendidikan merupakan bagian dari keseluruhan hidup manusia di dalam segala aspek sosial. Pendidikan nasional dilihat sebagai potret buram yang harus diperbaiki (Muhaimin, 2004).

Pendidikan agama sebagai media penyadaran umat dihadapkan pada problem bagaimana mengembangkan teologi pluralis, sehingga di dalam masyarakat akan tumbuh pemahaman yang pluralis dan toleran untuk 
harmonisasi agama-agama di tengah-tengah kehidupan masyarakat. Tertanamnya kesadasaran pluralitas agama-agama akan menghasilkan corak paradigma beragama yang hanif dan toleran. Ini semua harus dikerjakan pada level bagaimana membawa pendidikan agama ke dalam paradigma yang toleran dan berkeadilan.

Dari sisi filosofis, pendidikan agama yang hanya membenarkan agamanya sendiri (eksklusif) tanpa mau menerima kebenaran agama lain mesti mendapatkan kritik untuk selanjutnya dilakukan reorientasi. Konsep iman-kafir, muslim-nonmuslim, dan benar salah (truth claim) yang sangat berpengaruh terhadap cara pandang masyarakat terhadap agama lain, mesti dibongkar agar umat tidak lagi menganggap agama lain sebagai agama yang salah, dan tidak ada jalan keselamatan. Jika cara pandangnya bersifat eksklusif dan intoleran, maka teologi yang diterima adalah teologi eksklusif dan intoleran, yang pada gilirannya akan merusak harmonisasi agama-agama dan sikap menghargai kebenaran agama lain.

Begitu juga, guru-guru agama di sekolah sebagai ujung tombak pendidikan agama dari TK sampai Perguruan Tinggi, nyaris tidak tersentuh oleh gelombangpergumulan pemikiran dan diskursus pemikiran keagamaan di seputar isu pluralisme dan dialog antar umat beragama. Padahal guruguru inilah yang menjadi mediator pertama untuk menterjemahkan nilainilai toleransi dan pluralisme kepada siswa, yang pada tahap selanjutnya ikut berperan aktif dalam mentransformasikan kesadaran toleran secara lebih intens (Baca... Walid, 2005).

Karena itulah, meminjam filsafat pendidikan yang dikembangkan Paulo Freire bahwa pendidikan difungsikan untuk pembebasan, bukan untuk penguasaan (dominasi). Pendidikan harus menjadi proses pemerdekaan, bukan penjinaan sosial budaya (social and cultural domestication). Pendidikan bertujuan menggarap realitas manusia, dan karena itu, secara metodologis bertumpu pada prinsip-prinsip aksi dan refleksi total, yakni prinsip bertindak untuk merubah kenyataan yang menindas dan pada sisi simultan lainnya secara terus-menerus menumbuhkan kesadaran akan realitas dan hasrat untuk merubah kenyataan yang menindas (Baca ...Paulo Freire, 1990). 
Dengan cara pandang ini, pendidikan pembebasan untuk masyarakat dengan memberikan warna yang lebih terbuka dan toleran harus diberikan. Maka, yang perlu dilakukan adalah mendekonstruksi visi pendidikan agama yang berbasis eksklusif ke arah penguatan visi pluralis. Hal ini dilakukan karena kegagalan dalam mengembangkan semangat toleransi dan pluralisme dalam pendidikan agama akan menyuburkan radikalisme agama. Sebaliknya, keberhasilan dalam menumbuhkan sikap toleran dalam pendidikan agama, akan semakin menciptakan cita-cita perdamaian antar agama. Inilah yang harus kita renungkan dan diwujudkan agar pendidikan agama tidak menyumbangkan benih-benih konflik antar agama.

Karena itulah, kebijakan pendidikan yang.mengabaikan arti penting keanekaragaman dan kemajemukan agama-agama tidak akan menciptakan kehidupan yang toleran dan pluralis seta tidak akan dapat mewujudkan kerukunan bangsa, bahkan dapat menimbulkan tragedi kemanusiaan. Inilah yang harus diantisipasi untuk merancang sistem pendidikan nasional yang tidak hanya mengandalkan penguasaan materi (kognisi), tetapi juga bagaimana membentuk kesadaran beragama dalam tata cara pergaulan bermasyarakat yang damai tanpa konflik. Merancang sistem pendidikan agama yang dapat menampung nilai-nilai luhur yang mendasari kehidupan bermasyarakat yang lebih substansial, yakni pencerdasan kehidupan sosial secara lebih luas. Dengan logika paradigma pendidikan agama yang seperti ini, akan tercipta sistem pendidikan nasional yang menghargai pluralitas, bersikap toleran, dan mengupayakan kehidupan damai di tengah-tengah masyarakat.

Dengan kekhawatiran terhadap hancurnya ranah kemanusiaan, pendidikan agama seharusnya dikembangkan, sehingga melahirkan para pemeluk agama yang dapat menghargai perbedaan dan menjunjung tinggi nilai-nilai kemanusiaan universal. Apalagi, agama memang memiliki nilainilai universal. Martabat umat manusiabersumber dari keterciptaan manusia, bukan pada etnis dan agama yang dianutnya. Martabat kemanusiaan itu hendaknya dihormati oleh siapa saja dan menjadi sesuatu yang melekat pada diri setiap manusia. Kewajiban kita sebagai manusia ataupun warga negara yang baik hanya mengakui martabat sesama manusia yang diakui dan dilindungi oleh negara dari berbagai pelanggaran. 
Di sekolah atau madrasah, siswa hendaknya dibebaskan dari sekatsekat primordial. Pendidikan agama hendaknya lebih menekankan nilainilai pluralisme dan kebersamaan. Metode yang dikembangkan pun bersifat dialogis dan tidak indoktrinasi. Siswa diajak berekreasi terhadap realitas kemajemukan, sekaligus menggali nilai-nilai kemanusiaan. Siswa ditradisikan "bagaimana membangun kebersamaan dengan sesama"?, bukan siapa saja yang bersamaku (berdasarkan agamaku).

Contoh yang seperti ini sebenamya banyak ditemui dalam semua kitab suci dan tradisi keberagamaan umat. Dalam Islam misalnya, dikenal paradigma toleransi yang disebutkan dalam al-Kaafirun ayat 6, sesuatu yang sama juga disebutkan dalam agama-agama lain. Dengan paradigma pluralis itu, pendidikan agama akan menjauhkan diri dari memori saling bermusuhan. Misalnya, dalam otonomi daerah, semua pihak yang memegang otoritas pendidikan, khususnya pemerintah daerah, ikut berperan serta memfasilitasi pendidikan agama yang berorientasi pada pluralitas, sehingga dapat mengeliminasi kerawanan konflik antar agama dan umat beragama. Pendidikan agama hendaknya dapat membebaskan diri dari model pendidikan lama yang menekankan hafalan dan yang menekankan eksklusifitas.

Oleh karena itu, kurikulum pendidikan harus digagas dengan kerangka pluralisme oleh guru-guru agama yang berpengalaman dan berwawasan kebangsaan. Selain itu, kurikulum perlu dipenuhi oleh kearifan lokal, adat dan etnis, sehingga pendidikan agama menjadi dibutuhkan oleh siswa.

Namun demikian, betapapun baiknya kurikulum pendidikan agama, guru tetap merupakan faktor kunci yang paling menentukan. Guru agama berperan sebagai agen rekonsiliasi. Di tangan guru yang kreatif, dapat dimasukkan unsur-unsur kebersamaan lintas agama dan strata sosial lainnya. Dengan hidup dalam komunitas majemuk, murid dapat belajar dan melihat kemanusiaan dalam diri orang lain secara manusiawi, lepas dari identifikasi etnis dan ideologi. Dari sini, guru dapat dicitrakan secara positif, yakni guru agama yang dapat mendorong lahirnya kesadaran kolekțif para siswa berdasarkan nilai-nilai toleransi dan saling menghargai. Keadilan dibicarakan dalam perspektif hukum masyarakat beradab, bukan hukum yang kuat yang menang. 
Dengan cara seperti itu, memori siswa yang selama ini serba tunggal dari satu aspek ideologi saja akan mengalami transformasi. Para siswa dapat menghayati spritualitas yang pada gilirannya mampu mematahkan potensi rantai kekerasan dan permusuhan menjadi perdamaian, toleransi dan pro keadilan. Tragedi permusuhan tinggal menjadi sejarah masa lampau. Yang terjadi berikutnya, akan lahir generasi masa depan bangsa dengan mindset baru yang lebih pluralis.

\section{Kesimpulan}

Oleh karena itu, peran pendidikan agama dalam membentuk sikap pluralisme yang mengakui bahwa agama lain juga sama-sama sah dan mempunyai nilai kebenaran merupakan suatu keharusan. Maraknya gejala klaim kebenaran dapat berakibat pada terjadinya konflik secara sangat mengerikan. Bahayanya, agama dijadikan justifikasi untuk membenarkan berbagai perbuatan sadis dalam berbagai konflik terbuka.

Peran sosialisasi agama dalam membentuk sikap pluralis tidak dapat hanya mengandalkan bentuk, melainkan juga esensi. Hal yang perlu diperhatikan dalam pluralisme di sini bukan hanya sekedar mengatur kehidupan beragama, akan tetapi memberikan ruang sosial dan politik secara terbuka bagi segala hal yang terkait dengannya. Atau istilah tehniknya, pluralisme bukan hanya masalah prosedural dan dipahami sebagai kenyataan yang tidak bisa ditolak bahwa rakyat Indonesia adalah bangsa yang majemuk, melainkan perlu pemahaman lebih mendalam tentang situasi dengan mengakomodasi berbagai persoalan yang melingkupinya.

Dalam konteks peranan agama, pluralisme bukan berarti suatu sikap basa-basi dari pergaulan sosial, tetapi harus berangkat dari ajaran agama dan dari teologi baru. Inilah perlunya membangun suatu teologi pluralis, bahkan lebih dari itu, suatu teologi agama-agama, suatu paham teologi baru yang memberi tempat bagi keabsahan agama lain. Hal ini dengan meyakini bahwa di luar agama yang diyakini pada dasarnya terdapat kebenaran yang dimiliki oleh agama lain, walaupun masing-masing agama mempunyaijalan atau tata cara yang berbeda. Islam menyebut perbedaan itu hanyalah terletak pada segi syariah (jalan) dan manhaj (metode) saja yang kesemuanya 
mengacu kepada Tuhan yang satu, yaitu Allah swt. Sebuah paham yang mengajak umat beragama kepada kalimatun sawa' (titik temu) pada Tuhan, untuk akhirnya sama-sama mengejar kebaikan.

Dengan begitu, memang tampaknya sikap pluralis adalah jalan yang paling menantang dewasa ini, di tengah-tengah pilihan sikap ekslusif, tertutup bahkan fanatik, dalam melihat hubungan antar agama. Dalam bahasa agama, pluralisme itu bahkan merupakan ketentuan Tuhan agar manusia saling mengenal, saling memperkaya sebagai suatu kesatuan umat manusia. Sebagaimana ditegaskan dalam al-Qur'an surat al-Hujurat [49]: 13; "Dan kami jadikan kamu laki-laki dan perempuan, berbangsa-bangsa dan bersuku-suku, supaya kamu saling kenal-mengenal".

\section{DAFTAR PUSTAKA}

Buchori, Mochtar. 1992. Posisi dan Fungsi Pendidikan Agama Islam Dalam Kurikulum Perguruan Tinggi Umum. Makalah dalam Seminar Nasional di IKIP Malang, 24 Februari 1992.

Fadjar, Malik. 2004. Pendidikan, Agama, Kebudayaan dan Perdamaian. Malang: UIN Press.

Freire, Paulo. 1990. Pedagogy of the Oppressed. New York: Continuum.

Hanif, Abdullah. 2003. Redefinisi Pendidikan Agama. Dalam Reorientasi Pendidikan Agama, INOVASI, Depag RI dan Institute for the Study of Religion and Democracy.

Jawa Pos, 11 Mei 2003.

Muhaimin, 2004. Pendidikan Agama Islam Berwawasan Rekonstruksi Sosial.

Makalah disampaikan dalam rangka Pengukuhan Guru Besar UIN Malang.

Simposium Kebangkitan Jiwa. Pikiran Rakyat, 7 Maret 2002.

Russel, Bertrand. 2000.Education and Social Order.

Sururin (ed.). 2005. Nilai-Nilai Pluralisme dalam Islam. Bandung: Nuansa.

Schweitzer, Albert. 1950. Reverence for Life: An Anthology of Selected Writing. 
Towaf, Siti Malikhah.1996. Pembinaan Kampus Sebagai Lembaga Pendidikan Ilmiah Edukatif Yang Religius. Makalah Dalam Konvensi Nasional Pendidikan Indonesia III, di Ujung Pandang, 4-7 Maret 1996.

Walid, Muhammad. 2005. Kecenderungan anti Pluralisme Guru-Guru Pendidikan Agama Islam (GPAI) SMA di Malang. Laporan Penelitian.

Warsono dkk. 2006. Model Pendidikan Multikultural Sebagai Sarana Peningkatan Wawasan Kebangsaan Siswa Madrasah Ibtidaiyyah. Ulul Albab. Vol. 7, No. 1 Tahun 2006.

Zada, Khamami, 2003. Menabur Inklusivisme Pendidikan Agama. Dalam Reorientasi Pendidikan Agama, INOVASI, Depag RI dan Institute for the Study of Religion and Democracy. 